\title{
French plan to exploit genome sparks row ...
}

Evry

France last week launched a FF1 billion (US\$153 million) research effort, called GenHomme, to generate economic benefits from the post-sequencing phase of the human genome project. The programme was launched by Claude Allègre, the research minister, and Christian Sautter, the economics minister, in the presence of prime minister Lionel Jospin.

But a decision to restrict the public release of annotated data - sequences in which the structure and function of genes have been identified - may put France on a collision course with its partners in the publicly funded human genome project.

The launch took place at the Genopole, France's fledgling 'genetics valley', at Evry on the southern outskirts of Paris. The Genopole will be the core of the nationwide consortium of public laboratories and private companies that is being formed to run the programme.

Members of the consortium from the private sector are likely to include the pharmaceutical companies Pasteur Mérieux Connaught, Rhône-Poulenc Rorer, and biotechnology companies, including Genset and Transgene. Public-sectors members will include the National Sequencing Centre, the National Genotyping Centre, research centres in Toulouse, Strasbourg, Montpellier and Lille, and the Pasteur Institute in Paris.

According to Alain Henault, Allègre's technical adviser for genome affairs, the consortium will be open to all, including foreign companies, if they comply with a charter governing the terms of collaboration.

Five of the charter's six clauses concern confidentiality. One says that annotated sequences cannot be submitted to public databases before they have been subject to intellectual property protection. Another forbids participants from communicating results "either orally or in writing" without permission from their partners, who will have 60 days to decide whether to allow or delay publication.

Allègre said last week that GenHomme "clarified the position on intellectual property from the outset," arguing that this was "important, to avoid controversy later". But he may have been over-optimistic. Shown a copy of the charter, Jean Weissenbach, the head of the National Sequencing Centre, who has complained to Jospin about US companies holding back genome data, said that he had not seen it before and would refuse to sign it

Pierre Tambourin, the head of the Genopole, also claimed ignorance of the charter's details. He said he was "not in agreement" with its restrictions on submissions to public databases. But Jacques Demaille, director of

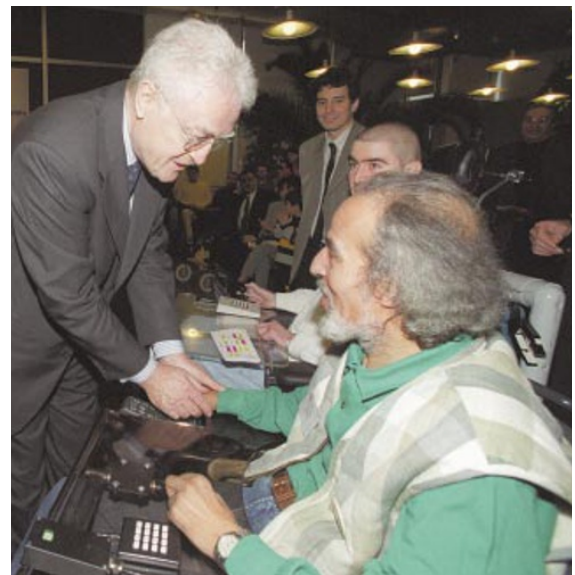

Helping hand: Lionel Jospin meets sufferers from genetic diseases at the launch of GenHomme.

the science ministry's genome activities, says that the charter is not open to negotiation. "Weissenbach is under no obligation to sign it," he says - adding that, if he refuses, he would be unable to participate in GenHomme projects.

Henault says that "collaboration with the private sector is impossible without such confidentiality clauses". But France's robust approach to intellectual property seems likely to reopen the international debate over access to sequence data.

Axel Kahn, a prominent French geneti- cist, who is also deputy scientific director for health and agricultural biotechnology at Rhône-Poulenc, says that protecting annotated data is acceptable in an industrial collaboration, for example on a particular gene. But "it is highly contestable, if we are talking about protection of sequences that are publicly available and have been annotated 'in silico' [by computer]".

The Bermuda agreement, which requires that all genome data be made public within 24 hours, only covers raw sequence data. But David Bentley, head of human genetics at the Sanger Centre at Cambridge in the United Kingdom, says: "I would strongly argue in favour of the open and free release of interpretation and annotation that leads to a better understanding and a more accessible genome".

Bentley says he would "welcome clarification" from the French government, as to what it will patent. Such clarification will also be needed "to see how this would impact on the international collaborative scene after the sequence is completed".

In 1997, Germany withdrew plans to give industry privileged access to sequence data from its national programme, after the United States, the United Kingdom and France threatened to withhold their data from German scientists and companies (see Nature 387,536 ; 1997).

Declan Butler

\section{... while Japanese sequencers feel neglected}

\section{Tokyo}

Leading Japanese researchers have raised doubts about the management of the country's genome research. The warning has come despite the celebratory mood surrounding last week's announcement of the sequence of chromosome 22, in which researchers at Keio University School of Medicine played a key role (see Nature 402, 447; 1999),

Speaking at a press conference in Tokyo to announce the achievement, Nobuyoshi Shimizu, Japanese partner of the chromosome 22 team, said that the government is concentrating too heavily on post-sequencing research, at the expense of genome sequencing itself.

Shimizu, professor of molecular biology at Keio, says the government is "attempting to skip sequencing" to focus on functional genomics. The shift to post-sequencing research, including the analysis of singlenucleotide polymorphisms and full-length complementary DNA, reflects Japan's concern over its limited sequencing capacity (see Nature 399, 96; 1999).

While acknowledging the significance of such research, Shimizu stresses the importance of support for sequencing the human genome. "Given Japan's limited sequencing capacity, there is a feeling within the government that further investment [in sequencing research] would not be worth the effort," he says.

Kenichi Matsubara, deputy director of the International Institute for Advanced Sciences and a pioneer of Japan's human genome project, blames the country's poor track record in genome sequencing on inefficiencies in the government funding system and its failure to promote genome research in a coordinated way.

According to Matsubara, the current system, under which different ministries carry out individual genome projects, has wasted money and made the allocation of funding unclear. "By the time the money is split among five different ministries, there seems to be very little left for actual research," he said at last week's press conference.

Despite the launch of a genome-research centre at the Institute of Physical and Chemical Research (RIKEN) last year, Shimizu says this has caused the allocation of funding to become biased. Although RIKEN and Keio University are sequencing 20 per cent of chromosome 21, "the money has all gone to RIKEN, and we have to make do with just seven sequencers and no funding increase," he says. Asako Saegusa 